\title{
The effects of the relationship between business strategies and information technology strategies: the telecommunication sector of Zimbabwe.
}

\author{
Chivandi, A ${ }^{1,2}$.,Mutanga, K.P ${ }^{2}$, and Musungwini ,S. ${ }^{2}$ \\ ${ }^{1}$ School of Economics and Business Sciences, Faculty of Commerce, Law and Management, University of the \\ Witwatersrand, Private Bag 3, WITS, 2050, Johannesburg, South Africa. \\ ${ }^{2}$ Department of computer science and information system, Faculty of Science and Technology, Midlands State \\ University, Private Bag, 9055, Gweru, Zimbabwe
}

\begin{abstract}
The relationship between business strategies and IT/IS strategies is one of the most important aspects of the management in the telecommunication organisations. The dramatic increase in the role of IS/IT in business and industry lately recognized as IS/IT became an inseparable part of business and industrial organizations in all sectors including government. IT delivers a value to the business and it is an important aspect to the top management and IT managers in many business firms and industrial organisations today. The purpose of this research explored the current relationship between business strategy and Information Systems strategy in the telecommunications sector in Zimbabwe, identified strategic alignment assessment methods that can be drawn from other countries for possible adoption by the industry in Zimbabwe, challenges posed by IS strategies and the solutions that management can implement and balancing the business strategy and IS strategy that gave competitive advantage insupporting their business objectives the telecommunications industry. The research was undertaken by examining the four telecommunications companies in Zimbabwe, Telecel, NetOne, Econet and TelOne. A survey, via a pretested questionnaire based on a Likert scale and indepth interviews was used to gather data. The results indicated that the companies have business strategies and IS/IT strategies and IT strategies showedless positive relationshipin supporting the business strategies. The research proposed that the telecommunications companies must employ strategies that support their business objectives. This enables them to assess and improve their current level of strategic relationship and maintain an optimised level.
\end{abstract}

Keywords: Business strategy, IT Strategy, Relationship, IS strategy, IT management, Business management, Telecommunication.

\section{Introduction}

The study is concerned with the relationship between business strategies and IS/IT strategies in the telecommunications sector in Zimbabwe. Information technology (IT) is a very important part of an organisation's daily operations and its strategic business. IT has been long viewed as a technological resource that would help organisations does better things (Hedman \&Kalling, 2002). Over the past three decade there has been rapid change in technology, more so in the area of information technology (Manzoni and Angehrn 1988). These changes are filled with "startling innovations and drastic unpredictable shifts in technology's direction". (Benemati and leader, 2000) They have enhanced the way business is done, providing competitive advantage for those who adopt them. This has necessitated the need for business to adapt and change continuously to stay ahead of the competition (Jaska and Hogan, 2006). The role of the information technology (IT) function and its relationship to other business functions is under constant and growing examination. As IT has become a necessary part of organisations, the interaction between the organisation's IT unit and other units is a key determinant of organisational success (Gordon \& Gordon, 2000; Ramakrishma and Lin 2000). Information technologies such as data communication systems, database management systems, decision support systems and expert systems, enterprise resource planning systems, the internet have been and will continue to cause monumental changes in the conduct of business activities (Tavakolian, 1991). This underscores the need for IT to be effectively and efficiently organized so that businesses can reap the full benefits from its IT investment. This research will describe how aligning IT strategies to business strategies affect the operations of businesses in the telecommunications sector in Zimbabwe.

\subsection{Background of the study}

According to Kaplan $\mathrm{J}$, for a competitive advantage to be created in an organisation, it is vital that their business and information technology strategies and processes are aligned. Although, strategic relationship has a history of being rated as a top issue facing business and IT executives, no single solution has been established to 
address this issue. Organisations today operate in dynamic and constantly changing environments, requiring continuous assessment of strategic relationship to ensure that they operate at optimal level. A key success factor for a successful company in a dynamic environment is effective and efficient information technology supporting business strategies and processes. Combining the business strategy with the Information systems strategy has become a vital concern in the planning process of organizations. The Telecommunications sector is becoming a rapidly developing industry in Zimbabwe as from the advent of the mobile systems. The technological developments in the world require businesses to use Information systems more than they used to do. It is important to establish relationships between the various resources in order to meet the organizational goals. These relationships contribute to the overall control, creativity, flexibility and knowledge of the organization and support the organisation's allocation of core business analysed with respect to the role that IS/IT plays in supporting the integration of these processes. The concept of integrating a business plan with information systems planning was first emphasized by King (1978). His methodology argued that an information systems strategy should be based on the organisational strategy. IBM has adopted this methodology in its business systems planning. The relationship between business needs and IT capabilities is therefore still a prominent area of concern.

Therefore, it is essential that organisations know how to utilise IT, so that IT resources are optimally employed to meet organisational objectives. Over time, information technology has rapidly advanced in capability and has changed the way organisations do business. In changing the organisations strategy to meet with changing business environment, research suggests it is equally important for the IT function to be aligned with business to reap its full potential benefits (Korde Luc 2004). The rapid changes in IT has propelled it into an increasing strategic role in organizations and as such also affect the way IT function is organized.Information systems strategies and business strategies in the Telecommunications industry in Zimbabwe do not complement each other. These companies, both the fixed network service providers and mobile networks, do face common problems in the modern business environment. The recent mass introduction of IT has confused the issue of information management and information provision. These companies do not know how to strategically balance and identify ways in which Information systems strategies and business strategies can contribute to the business in order to increase corporate performance.It is, therefore, apparent that there is need to analyse on the current relationship between business strategies and the IS strategies in the telecommunications sector in Zimbabwe with the view to identify the strengths and weaknesses, and eventually coming up with suggestions for improvement.

\subsection{The Importance of Business and IT Strategy Alignment}

\section{Literature review}

Many authors have established that strategic alignment is important, and that it improves business performance (Kearns and Lederer, 2000; Croteau and Bergeron, 2001; Sabherwal and Chan, 2001; Cheo, 2003).

According to Papp (2001) misaligning business strategies and IT strategies can cause problems with not only the development and integration of business and IT strategies, but can actually prevent IT from being leveraged to its maximum potential within an organisation. Although most organisations recognise the significance of strategic alignment, very few believe they are doing it correctly (Beal, 2004). According to Luftman (2000), alignment addresses both: doing the right thing (effectiveness) and doing things right (efficiency).

Guttman (2004) noted that when IT and business strategies are properly aligned, the various parts of an organisation move synchronously to achieve results. This is supported by Puth (2002) who highlights that alignment within an organisation ensures that activities throughout the organisation are directed towards the achievement of shared goals. Furthermore, Luftman and Brier (1999) state that strategic alignment is important, as it can build a strategically viable advantage that will provide organisations with increased visibility, efficiency, and profitability to operate in today's ever changing markets. It further allows an organisation to respond more quickly to dynamic and changing business environments, thereby using IT to achieve its set goals and objectives.

According to Luftman (1999), there is little doubt of the elevated importance of strategic alignment, which has been documented since the late 1970's. The reasons for alignment being sought after vision in an organisation range from the efficient use of resources and expenses reduction, to maintaining a competitive advantage. Alignment thus ensures that organisations remain fiercely competitive, high performing entities.

\subsubsection{Functional Integration and strategic fit}

The functional integration represents the horizontal relationship, which is an extension to the concept of strategic fit to the functional domain of the strategic alignment framework. As business strategies change, IT strategies and processes must also keep pace, and correspondingly, infrastructure and processes must keep pace as either business or information undergoes change (Coleman and Papp, 2006). A critical element of the SAM 
framework is the recognition that a functional strategy needs an external or market positioning perspective, where different relationships are defined. The ability of the firm to adapt and effectively leverage technology will effectively determine the firm's position in technology market. Functional integration offers IT the opportunity to provide competitive advantage to the firm (Luftman, 1993).

According to Henderson and Venkatraman (1991 \& 1993) strategic fit identifies the need to manage choices that both position the enterprise in an external marketplace and decide how to best structure internal arrangements of the enterprise to execute this market-positioning strategy. Those choices that position the enterprise in a market are referred to as business strategy, and those choices that determine the internal structure of the enterprise are the organisational infrastructure and processes. Performance of the enterprise is defined by the extent to which the choices consist of these two strategies are consistent, and as business strategies change, organizational processes are required to keep pace. Similarly, for the IT strategy and its IS/IT infrastructure and processes are required to be consistent. Using IT resources properly to enhance these vertical choices provides the opportunity for strategic advantages to the firm (Henderson and Venkatraman, 1991 \& 1993; Luftman 1993).

\section{Information Systems (IS)}

According to Ward and Peppard ( 2002) IS existed and used in organizations to manage business long before the advent of IT, and most IS were exclusively data- oriented with the primary purpose to store, retrieve, manipulate, and display data [Andriole, 2002]. IS can be defined as a system that includes persons and data records and management activities for managing and processing information, usually computer-based data processing system (computer- based information systems).

IS also refers to the systems that include computer hardware, software, and people and management policies and procedures, and that systems use the IT to store, manage, and process information which often relies on databases. The UK Academy of Information Systems (UKAIS) defines information systems, whether automated or manual as the means by which people and organizations, utilizing technology, collect and process, store and disseminate information to complete business tasks. IS involves the planning, analysis, design and maintenance of computer-based information systems used to process information. It is, therefore, an organized structure of interrelated components that is concerned with the purposeful utilization of information technology [Ward and Peppard, 2002].In Zimbabwe companies in the telecommunications sector do use information systems in some of their processes. The information systems are used in database management systems and operations of the networks.

Information Technology:IT is an engineering term that refers to a wide variety of items and abilities used in the creation, storage, and dispersal of data and information as well as in the creation of knowledge; Data are raw facts, figures, and details. Information refers to an organized, meaningful, and useful interpretation of data, while knowledge is the awareness and understanding of a set of information and how that information can be put to the best use" [Senn, 2004]. It is an engineering discipline that refers specifically to modern technology, essentially computer-based hardware and software systems, telecommunications networks, database management, and other information processing technologies and know-how used in computer-based information systems to create or enable the acquisition, representation, storage, transmission, and manage and use of information[Ward and Peppard, 2002; Sage, 2002].In the European union, the term Information Communication Technologies or ICT is generally used instead of IT to recognize the convergence of traditional information technology and telecommunications, which were once seen as distinct areas. In Zimbabwe the term ICT is also now being used instead of IT, which has also seen the birth of a ministry which stands on its own to represent this sector. The telecommunications companies fall under the ministry of ICT.

Business Strategy: The concept of strategy has been widely used in management research and literature, and a number of definitions of this concept have been presented by different scholars and researchers both in military and business management disciplines. In fact, there is no absolute consensus or single universally accepted definition of strategy. According to (Mintzberg, 2003) various authors and managers use the concept differently that might include other related terms such as goals and objectives as part of strategy, whereas others make firm distinctions between them.In a basic and simple definition, strategy is a management (planning) concept designed to achieve the basic long-term objectives or a particular goal of an organization or an enterprise. It is a pattern or a plan that integrates an organization's major goals, policies, and action sequences forming up a cohesive whole [Mintzberg , 2003]. Strategy is the determination of the steps required to reach an objective that makes the best use of available resources. It is a top management duty that is of great importance to the organization. The strategy is therefore constrained to the business nature of the organization, including its resources, capabilities, culture, structure, and the business environment within which it operates. It constructs a framework that consists of an integrated set of actions aimed at increasing the long-term well-being and strength 
of the organization relative to competitors, which helps to ensure that the organization makes the best use of what it has to work with and adequately compensates for its limitations [Robson, 1997; Ward and Peppard, 2002]. The concept of strategy has been borrowed from military and adapted for use in business to achieve the firm's short term objectives and long term plans [Mintzberg, 1987; Sadler, 2003].

Strategy is a very interesting and a complex discipline. It is a wide subject that has been defined and interpreted by different scholars and authors in different perspectives. According to Henry Mintzberg, 2003, five definitions of strategy are presented:

Strategy as plan - Which refers to some sort of consciously intended course of actions, a set of guidelines to deal with a situation.

Strategy as ploy - Which refers to specific manoeuvre intended to outwit an opponent or competitor.

Strategy as pattern - Which refers to specifically, a pattern in a stream of actions.

Strategy as position - Specifically, a means of locating an organization in a dynamic business environment, where strategy becomes the mediating force between the organization and its business environment, that is, between internal and external context.

Strategy as perspective - Which refers to deeply and thoroughly worked way of perceiving the world [Mintzberg, 2003].

IS Strategy:is concerned mainly with aligning IS development with business needs and trying to gain a strategic advantage through the proper using of IT in the firm [Earl, 1989]. It is a planning process for the development of systems towards some future vision role of information systems in the organization. IS strategy defines the organization's demand for IS/IT - the requirements or 'demand' for information and systems to support the overall business strategy. It brings together the business aims of the organization, a clear understanding of the information needed to support those aims, and the implementation of computer systems to provide that information. IS strategy is firmly grounded in the business, taking into consideration both the competitive impact and relationship requirements of IS/IT. Basically, IS strategy defines and prioritizes the investments required to achieve the 'ideal' application portfolio, the nature of the benefits expected and the changes required to deliver those benefits, within the constraints of resources and systems interdependencies [Allen, 1995; Ward and Peppard, 2002].

A good approach to present the general components of IS strategy and the interrelationships of these components to conceptualize how IS fits into an organization is to present them in a framework or model. This will help business and IT practitioners in exploiting IT efficiently for strategic advantage [Earl, 1989]. Different conceptual frameworks developed by different scholars and researchers in business and IS/IT that present the interrelationships between business, IS and IT strategies. Among these frameworks, for instance, the three levels of strategy in IS/IT presented in figure (1) [Earl, 1989] and an IS strategy components presented in figure (2.1) [Galliers, 1993]. These frameworks are almost similar with minor differences in the contents of their elements or the name of the components, and how these components are organized in each framework. The framework of the three level of strategy of IS/IT, developed by Michael J. Earl, consists of three domains that are represented in IS strategy, IT strategy, and Information Management (IM) strategy as depicted in figure (1), and each domain has its components. This model was much more explicit about the responsibilities for each domain, subtly, but significantly, suggesting a different balance between the IS function and general management in each domain [Earl, 1989 \& 1998].

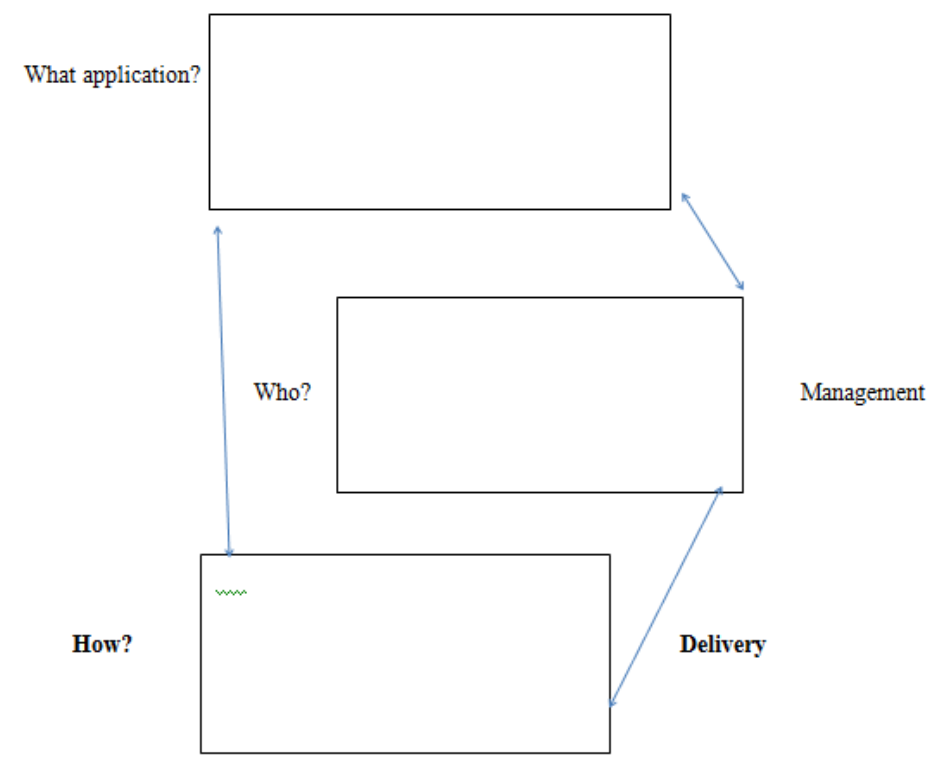




\section{Figure (2.1) Three levels of strategy in IS/IT ～(Source: Earl, 1989)}

Business Strategies in Zimbabwe Telecommunications: The telecommunications sector in Zimbabwe is also going through the rapid and continuous technological and economic changes which are driven by both external and internal factors. These pressures result in companies in this sector changing business strategies and also employ new and innovative strategies to meet the demands of the new world. The companies in Zimbabwe implemented a number of strategies which included:

Network Security - There are various threats to telecommunications equipment and systems which require security. The companies rolled out means to secure their systems which included fraud management systems and data security.

Marketing - The fierce competition in the sector is forcing the competing companies to come up with innovative strategies to market their products and services. The strategies include advertising in the print and electronic media as well as branding.

Strategic partnerships - Zimbabwean telecoms companies are for the idea of engaging foreign investors who can assist financially and technically. Econet Zimbabwe is a public listed company on the stock exchange, Telecel has foreign investors, Netone and TelOne are in the process of engaging foreign partners.

High technology - The telecoms companies in Zimbabwe are in the process of implementing projects that involve new technology in all their departments. Econet and TelOne are rolling out optic fibre network throughout the country whilst NetOne and Telecel do lease capacity from these others.

Infrastructure Development - The mobile telecommunications are increasing their capacities through installation of base stations utilising new generation technologies, which will cater for intelligent networks, wireless application protocol (WAP) and general packet radio services (GPRS) usage. The fixed network company (TelOne) is also installing new networks in areas that are being developed especially in urban areas through underground copper cables.

The telecommunications companies in Zimbabwe do have IT in their company structures where they develop strategies in line with IT which include the following:

Marketing - The companies do use their websites to IT Strategy: is concerned mainly with technology policies, and outlining the vision of how the organization's demand for information and systems will be supported by technology-essentially; it is concerned with 'IT supply' [Earl, 1989]. It addresses the provision of IT capabilities and resources (including hardware, software and telecommunications) and services such as IT operations, systems developments and user support [Ward and Peppard, 2002]. Basically, IT strategy is concerned with preferred methods, security level, mandated systems, the applications and platforms, the practical facts about how to provide the information [Earl, 1989]. Thus it concerns with the technological infrastructure necessary to fulfil the requirements of the information strategy, and provides the framework within which the specialists offer IT applications and users use them [Earl, 1989; Allen, 1995].According to (Jens Niebuhr, Andreas Spane, Dr.Germar Schroder, Dr.Florina Grone ) Telecom operators around the world are in a race to offer customers a multiplicity of converging products and services, to be paid for by equally complex and various pricing plans. This has resulted in companies developing IT strategies that meet the current world trends. The strategies include:

Billing strategy - The fixed-line operators phased out the copper services and replaced them with fibre-based, next -Generation access technology and also outsourced the systems to third-party providers. Mobile operators introduced Real-Time Billing systems that provided state of the art prepaid and post-paid facilities which offered both scalability and cost efficiency to the customers.

IP Based Strategy - Telecom companies have been investing in their networks make significant transformation of their platforms since they switched from analogue to digital systems. Although most are spending billions to adopt this technology, to date few of them have shown how to make IP profitable in serving their enterprise customers. Consequently, they are undertaking the IP transformation in the hope they will find the payoff somewhere along the way.

Marketing strategy - Marketing is the process of planning and executing the conception, pricing, promotion and distribution of ideas, goods, and services to create exchanges that satisfy individual and organisational goals. Telecommunications marketers face real challenges in today's world. Brand-name competitors promising customers a 'better deal' on services those traditional providers have historically dominated. As bundled voice, internet and video offers gain converts, getting the right message to your customers and prospects at the right time.

High speed internet - The telecoms companies deployed broadband in their networks. The beneficiaries of the broadband include the local network companies, along with a myriad of others including network equipment vendors, PC makers, chip manufacturers, software companies and media companies like AOL- Time Warner. In addition there are thousands of companies for which the internet is a low cost distribution channel.

Wireless systems - Telecoms companies introduced wireless technology. Wireless network refers to any type of computer network that is not connected by cables of any kind. It is a method by which homes, 
telecommunications networks and enterprises installations avoid the costly process of introducing cables into a building, or as a connection between various equipment locations.

Migration to Single packet network - This was a strategy to combine voice, data, image, and video into a single packet network. In the long-term, maintaining two parallel networks, circuit-switched for voice and packet-switched for data, was seen to be excessively expensive.

Digital Convergence - According to Nicholas Economides (1998) all voice messages are digitized close to their origination and are carried in digital form over most of the networks. Thus, the data and voice networks are one, with voice treated as data with specific time requirements.

\subsection{IT Strategies in Zimbabwe Telecommunications sector}

market their products and services, as well as the short message services platform for the mobile operators.

Billing - Mobile operators introduced Real-Time Billing systems that provided state of the art prepaid and postpaid facilities which offered both scalability and cost efficiency to the customers. The fixed network is using the post-paid billing system.

Expansion Strategy - Mobile companies introduced wireless internet access. Econet through its internet armEco web offered the first mobile information services in Zimbabwe, which would allow customers to access a range of SMS information services, such as stock exchange results and local newspaper reports. Econet also introduced mobile banking. The fixed network company (TelOne) has the dial up facility and the new product ADSL (Asynchronous Digital Subscriber Line) which enables its customers to access the internet.

Network Security - Telecommunications companies have developed a number of high level security requirements which include, Systems access control, fraud management systems, resource access controls, data and systems integrity, Audit trail.

Information strategyInformation strategy as defined by IT University of Oxford (1993) - is "a set of attitudes in which: any information that should be available for sharing is well defined and appropriately accessible (allowing for necessary safeguards); the quality of information is fit for its purpose (e.g. accuracy, consistency, completeness; all staff know, and exercise, their responsibilities towards information; there is a mechanism by which priorities are clearly identified and then acted upon" [ICT - University of Oxford].

The information strategy of an organization is a set of principles that acts as central cohesive source of support and stability between the business strategies and IS strategy [Galliers, 1993; Allen, 1995]. It defines the attitudes of that organization towards information and process by which it is required, manipulated and stored. Information strategy describes the priorities of development that will guide the information [UCL Information strategy]. The key objectives of the information strategy are to ensure information-gathering across the organization is carried out in the most effective way to improve business performance [Galliers, 1993; ICT University of Oxford; UCL Information strategy].

IT Management Strategy: IT and IM have a profound effect on an organization's strategic position because they fundamentally change both the mechanism of adding value and driving forces of industrial competition [Picot, 1989]. An important aspect of IT management is the question of how IS and IT can support the business strategy and the business goals. IT management is a discipline that includes managing people and business-IT processes. It is a management for the entire spectrum of technologies for information processing, including software, hardware, communications technologies and related services. The IT management strategy is primarily concerned with the role and structure of IT activities in the firm [Earl, 1989]. It embodies policies, organizational provisions, and management control for IT, management responsibilities, performance measurements and management processes, and a comprehensive set of activities associated with developing and managing the information resource. IT management strategy focuses on relationships between the specialist and users and between the centre and divisions or business units [Earl, 1989; 8Ward and Peppard, 2002]. In order to develop an overall organizational capability to exploit IS/IT effectively over an extended period, further aspects of IS/IT require coherent and consistent strategic management. IT management strategy is concerned with how information services are organized for a different facet or aspect of the organization (i.e.; centralized, distributed, out-sourced) and policy issues as who get access and what level of access they receive [Allen, 1995; Ward and Peppard, 2002]. The relationship between the component of IS Strategy and IT management strategy as well as with change management/implementation strategy is depicted in figure (2) [Galliers, 1993].

\subsection{The Relationship between Business and IT Strategies}

When the business and IT strategies are aligned, it ensures that the resources are incorporated within the overall strategic direction of the organisation, and focussed on areas that are critical to success. According to Ward and Peppard (2002), the contribution and performance that IT provides to organisations has become more significant. Hence, they highlight that the level of management involvement has advanced to the executive level. By focusing on technology alone, Earl (1992), in Ward and Peppard (2002) argues that it does not lead to successful strategic application. He suggests that the most effective way of achieving strategic benefits from 
IS/IT is by concentrating on the rethinking of business by analysing current business problems and environmental change, and considering IT as just one part of the solution. He highlights that a distinction needs to be made between IS and IT by suggesting that the IS strategy is concerned with technology, infrastructure and associated specialist skills, therefore addressing the "how" question. This relationship is illustrated by Ward and Peppard (2002) in Figure 2.3.

Figure 2.3 depicts how with IS/IT, an organisation first needs to identify the potential impact it could have on the organisation, secondly evaluate what information and systems are required to enable the delivery of the strategy, and finally determine the best way in which to attain the information systems via the technology (Ward and Peppard, 2002). This model however does not consider how changing business environments influence organisations. It merely serves to show the relationships. Ward and Peppard conclude that IS/IT must be carried out efficiently and effectively, like any other part of the business (i.e. marketing, production, purchasing), for the business to survive and provide a strategic edge. They highlight that this provide an approach of developing strategies for information systems and technology that are developed from and incorporated with other components of the business strategy.

Strategic alignment is not only critical for organisational effectiveness and efficient resource utilisation, but alignment must be present before information systems can be chosen and diffused to achieve maximum IT effectiveness (Chan and Huff, 1993) and to support business strategies (Teo and King, 1997). IT by itself does not explicitly offer a competitive advantage; however Kaplan (2003) indicates that if an organisation uses IT strategically to improve crucial business processes, it can strengthen their competitive position and enable a competitive advantage to be sustained.

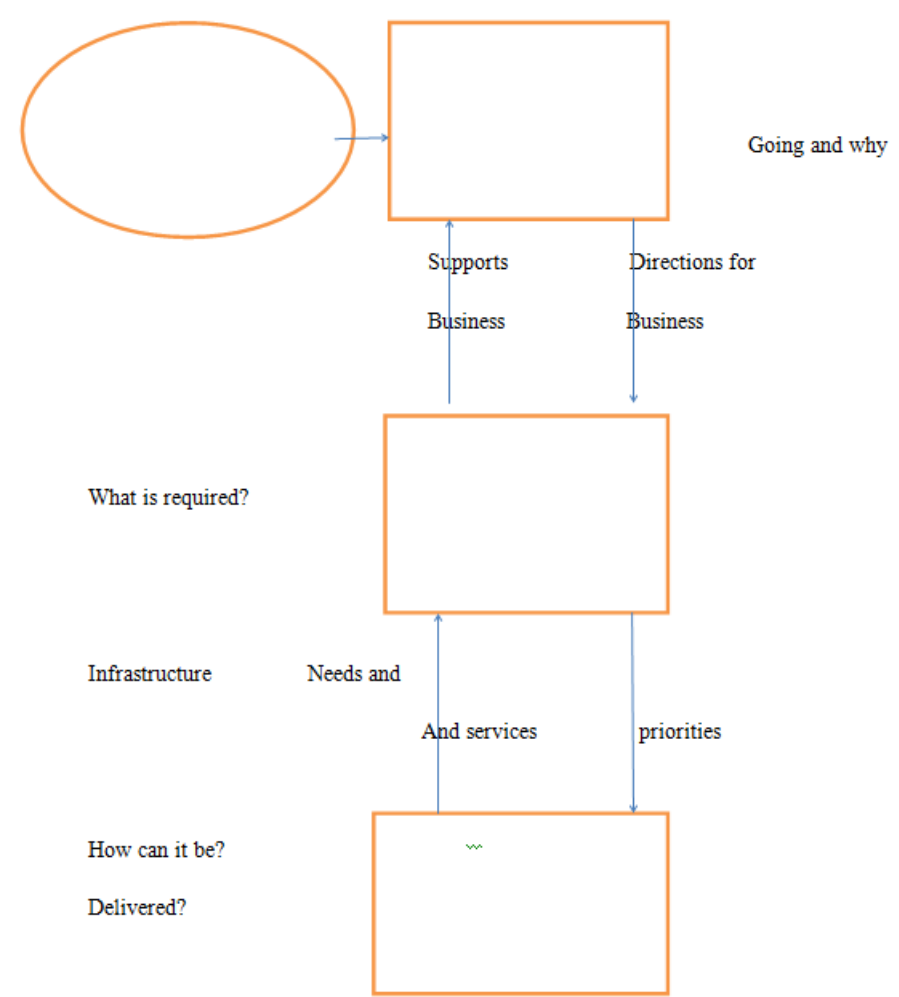

Figure 2.2: The relationship between Business, IS and IT Strategies (Source: Ward and Peppard, 2002: p41)

\subsection{Measuring the Information Systems - Business Strategy Relationship}

According to Reich and Benbasat there are a number of factors that influence the social dimension of alignment between business and information technology objectives. The social dimension of alignment refers to the state in which business and IT executives understand and are committed to the business and IT mission, objectives and plans. There are four common factors that would potentially influence alignment.

- Shared knowledge between business and IT executives - Boynton et al. (1994) suggest that effective application of IT depends on the interactions and exchanges that bind IT and line managers. Rogers (1986, p. 199) states that participants create and share information with each other to reach a mutual understanding. Such information sharing over time leads the individuals to converge or diverge from each other in their mutual understanding of a certain topic. According to Rockart et al. (1996) communication ensures that business and IT capabilities are integrated into business effectively. 
- Connections between business and IT planning - According to (Lederer and Burky, 1989) IT executives who participate more in business planning believe they have a better understanding of top management's objectives than those who participate less. Zikmud (1989) argues that structural mechanisms (e.g. steering committees, technology transfer groups) associated with communications and management systems (e.g., planning and control mechanisms) are needed to build IT-line partnerships for the successful introduction of new technologies. In the telecommunications sector the level of connection between business and IT planning processes will positively influence the level of alignment.

- Shared domain knowledge between business and IT executives - Shared domain knowledge is defined as the ability of IT and business executives, at a deep level, to understand and be able to participate in the others' key processes and to respect each other's unique contribution and challenges. According to Nelson and Coop rider's (1996, p. 411) shared knowledge construct, developed concurrently, (i.e., an understanding and appreciation among IT and line managers for the technologies and processes that affect their mutual performance) is very similar, although their operationalization differed. For the telecommunications sector the level of shared domain knowledge will positively influence communication between business and IT executives and connections between business and IT planning processes.

- IT Implementation success - In the telecommunications sector world over, the level of IT implementation success will positively influence the level of communication between business and IT executives and the connections between business and IT planning processes. According to Lucas (1975), failures reduce the credibility of IT departments and the confidence line managers have in the competence of IT departments. Failures also pose a threat to the working relationships between IT and business executives by lowering trust, cooperation, and support from users and management. A successful history of IT contribution is expected to increase the interest of business executives to communicate with IT executives and to have IT considered more fully and carefully in business planning because of the high value expected from IT utilization.

\subsection{Strategic Alignment Model (SAM)}

Previously, two conceptual frameworks were presented; the three level strategy in IT developed by Michael Earl [Earl, 1989], and Information Systems components developed by Robert D.Galliers [Galliers, 1993], which represented general frameworks that illustrate the interrelated components of IS strategy and their alignments with the business strategy. The general model of business-IT strategic alignment developed by John C. Henderson and N.Vankatraman [Henderson and Vankatraman, 1993] will be presented. The SAM model represents the dynamic alignment between the business strategic context. It is based on the building blocks of strategic integration and functional integration. The strategic alignment model is defined in terms of four fundamental domains of strategic choices that consist of: business strategy, information technology strategy, organizational infrastructure and processes, and information technology infrastructure and processes. Each domain has its own underlying dimensions that consist of three components as presented in figure (2.3) [Henderson and Venkatraman, 1991 \& 1993]. The components of the strategic alignment model are twelve components that further define business - IT strategic alignment [Luftman et al. 1993; Luftman, 2000].

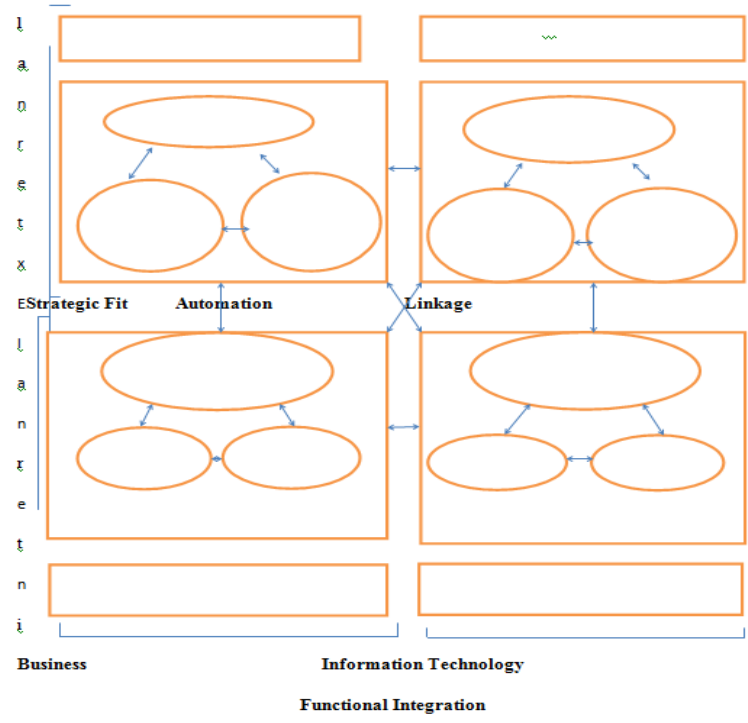

Figure 2.3 Strategic Alignment Model (Source: Henderson and Venkatraman, 1993) 


\subsection{Materials and Methods}

Since this research study investigated the relationship between business strategies and IT strategies in the telecommunications sector in Zimbabwe, the study indicated that it wasmore phenomenological not the positivist thus indicating that it was interpretive in nature. The questions contained in the created assessment method were subject to the choices of respondents, therefore indicating that the research was more subjective than objective in nature (Collis and Hussey, 2003) describe, subjective and interpretive research form part of the phenomenologist research paradigm. The systems theory concept was widely used as the study of the properties of a system as whole, so as to learn and understand the behaviour of the system in the real world. Both an organisation's external and internal environmental forces exert an influence on strategic alignment. These forces constantly influenced the four domains of alignment, namely business strategy, business infrastructure, IT strategy, and IT infrastructure. Changes in one of the four domains influenced the other domains, and strategic alignment as a whole.

\subsection{Study sites}

the study sites in this research was made up of management and IT personnel from mobile communications companies in Zimbabwe (NetOne, Econet and Telecel), the management and IT personnel of the fixed telecommunications company in Zimbabwe (TelOne), members of the public who uses the services of mobile and fixed telecommunications companies.

\subsection{Sample size}

Hussey and Hussey (1997:101) defined a sample size as a subject of population and should represent the main interest of the study." Brink (1996) defines a sample as "a part or fraction of a whole or subset of a larger set, selected by the researcher to participate in a research project". It is therefore the group that the researcher used was actually selected for participation in the study. In this study the researcher used business managers and IT personnel in all the three mobile telecommunications companies and one fixed telecoms company in Zimbabwe. The researcher also used a sample of members of the public who used landline and mobile telephones.

\subsection{Sample size and inclusion criteria}

In this study the researcher used simple random sampling. The researcher selected respondents at random from the members of public who uses telecommunications facilities offered by TelOne, Econet, Telecel and NetOne. Until a reasonable sample size was achieved. "Reasonable sample" refers to a sample size large enough for us to be reasonably confident that the sample represents the population. Respondents were from the top management of these organisations.

2.3 Data collectiona triangular method was used in this study, by adopting two different research techniques to collect the primary data, namely interviews and questionnaires. The questionnaires will be structured with closed and open-ended questions. Closed questions require the respondents to select an answer from given alternatives while open-ended questions which elicited the respondents to give their own views. The researcher administeredin depth structured questionnaires to users of the mobile network where a certain number of specific closed and open-ended questions were asked. Face to face interviews were conducted to top management complement the questionnaire and facilitate quick access to data. The reason for conducting qualitative interviews as Kinner and Taylor (1991) emphasise, is to raise the value of information and create a foundation for deeper and more widespread knowledge about a subject.

\subsection{Data analysis}

The questionnaire assessment was divided into three sections, that of mobile telecommunications companies, that of fixed network operator and the section on users of the services.Descriptive statistical analysis were used to interpret data. Forcese and Richer (1973) argued that descriptive statistics is commonly used because it is the basis for more advanced techniques. Ary, Jacobs and Razavieh (1990) argued that descriptive statistical procedures enable people to organize, summarize and describe their observations. Frequency Distribution was used whereby data was organized in tabular form. Bar charts and pie charts were also used to present the data graphically.

\section{Results}

The researcher administered three different questionnaires that targeted respondent categories and statistics of the distribution of the questionnaires and the corresponding response rates are shown in Table 4.1 below. 
The effects of the relationship between business strategies and information technology strategies: The

\begin{tabular}{|l|l|l|l|}
\hline Respondent Category & $\begin{array}{l}\text { Questionnaires } \\
\text { Dispatched }\end{array}$ & $\begin{array}{l}\text { Questionnaires } \\
\text { returned }\end{array}$ & $\begin{array}{l}\text { Response rate } \\
\mathbf{( \% )}\end{array}$ \\
\hline Telecel & 50 & 34 & 68 \\
\hline NetOne & 50 & 36 & 72 \\
\hline Econet Wireless & 50 & 39 & 78 \\
\hline TelOne & 50 & 41 & 82 \\
\hline Total & $\mathbf{2 0 0}$ & $\mathbf{1 5 0}$ & $\mathbf{7 5}$ \\
\hline
\end{tabular}

Table 4.1 Research instruments response rate

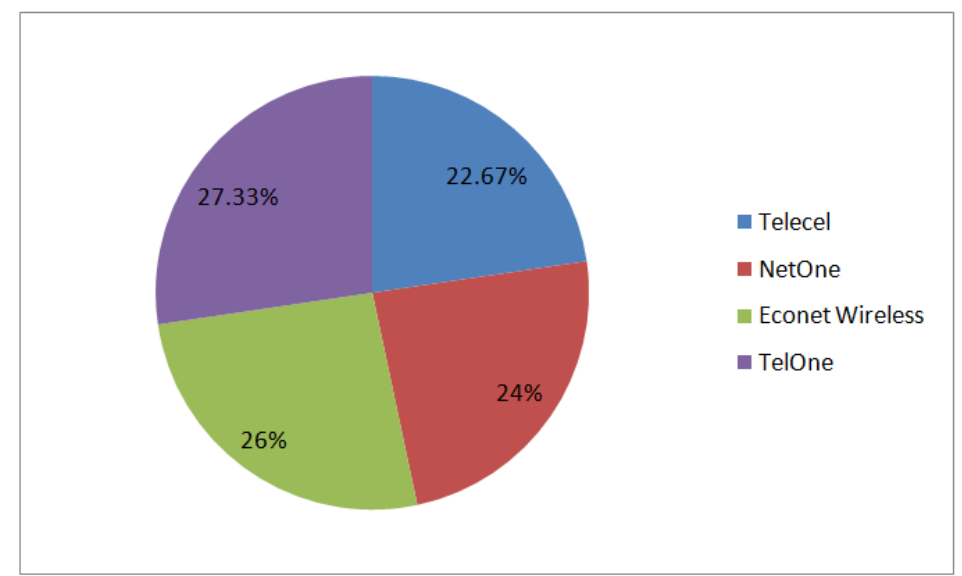

Fig 4.1: Questionnaire Response Rate

Telecommunications Managers' Questionnaire; Business Strategy

The respondents were asked to indicate if there is a business strategy in their organizations and their responses are displayed in Fig 4.2 below.

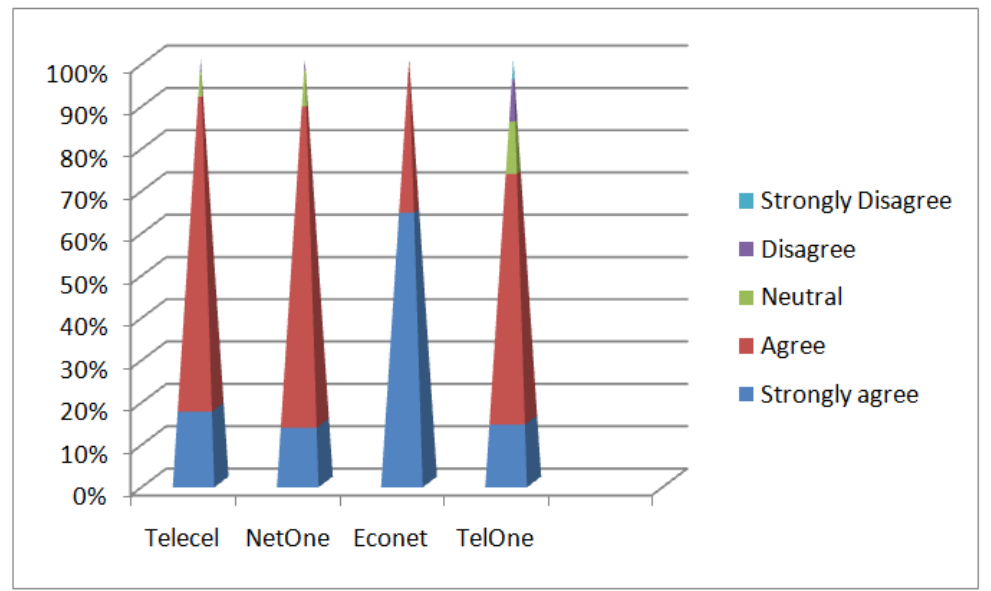

Fig 4.2: Is there business strategyRespondents from Econet wireless indicated that they were well aware of the business strategy and the response was $60 \%$ strongly agreed and 35\% agreed. From Telecel it was $14 \%$ strongly agreed and $74 \%$ agreed while $12 \%$ were not sure if there was a business strategy or not. NetOne had $10 \%$ strongly agree and $76 \%$ agreed while $14 \%$ were neutral. TelOne had $10 \%$ strongly agreeing that there is a business strategy and 60\% just agreed while 12\% were neutral and 9\% disagreed that there is a business strategy in the fixed network company. The statistics indicate that there are business strategies in the telecommunications sector in Zimbabwe.

IT Strategy; The respondents were asked to indicate if there is IT strategy in their organizations and their responses are displayed in Fig 4.3 below. 


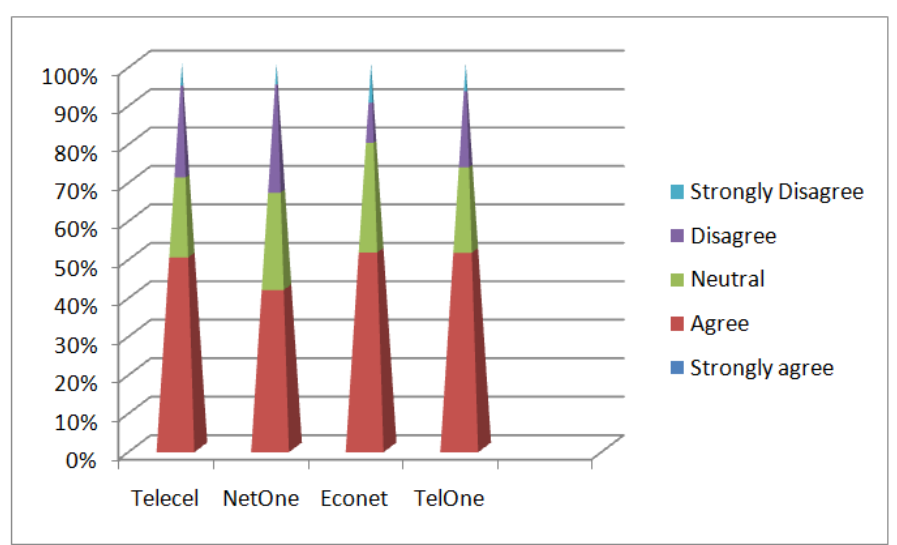

Fig 4.3: IT Strategy

Telecel management and employees had just $36 \%$ agreed that there was an IT strategy, $22 \%$ were neutral, that is they were not sure if the strategy was there or not, $30 \%$ disagreed that there was a strategy and $10 \%$ strongly disagreed. Respondents from NetOne had 26\% agreeing that there is IT strategy, $26 \%$ were neutral, $38 \%$ disagreed and $10 \%$ strongly disagreed. For Econet $0.01 \%$ strongly agreed, $39 \%$ agreed, $28 \%$ were neutral and $28 \%$ disagreed that there was an IT strategy. In TelOne 15\% agreed that there was an IT strategy, $25 \%$ were neutral and 50\% disagreed .IT strategies are there in the telecommunications sector but they are not that pronounced as compared to business strategies.

\section{Relationship between Business strategy and IT Strategy}

The respondents were asked if business strategy and IT strategy were separate entities in their organisation and their responses are displayed in Fig 4.4

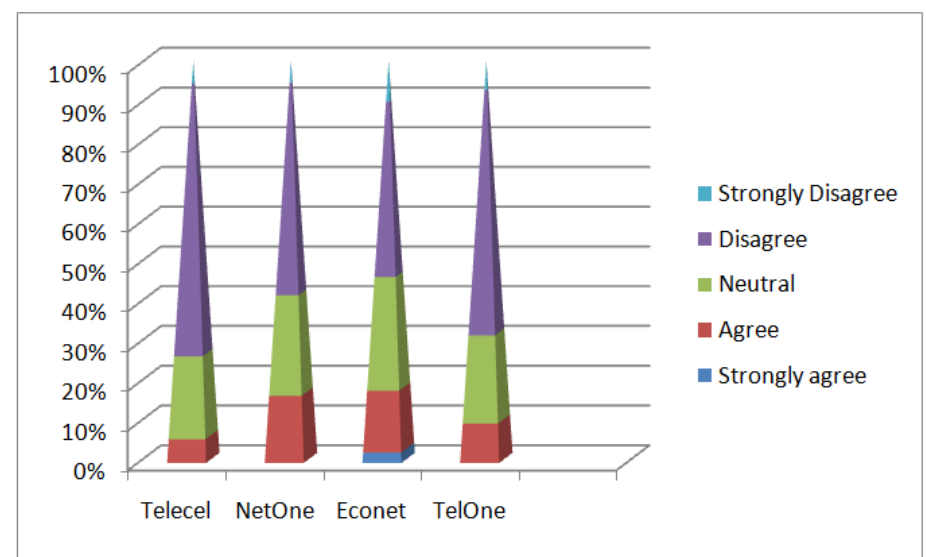

Fig 4.4: Relationship between Business and IT Strategies

$47 \%$ of Telecel managers and employees agreed that the IT strategy and business strategy are separate entities and $21 \%$ were not sure if the two were separate with about $12 \%$ disagreeing that the two strategies were separate. NetOne had $38 \%$ agreeing that the two strategies were separate entities and $25 \%$ were neutral that is they were not sure if the business strategy and IT strategy were separate entities. Econet had $47 \%$ agreeing that the two were separate entities and $28 \%$ were neutral, that is they could not decide if the two were separate entities. Telone had $47 \%$ agreeing that the business strategy and IT strategy of the company are separate entities, $23 \%$ were neutral and $19 \%$ disagreed that the two strategies were separate entities. The statistics show that there is no relationship between the business strategies and IT strategies in these organizations. Managers and employees do concur that although there are business strategies and IT strategies they do not see the two being related in the way they are implemented.

\section{Business-IT strategy relationship}

Respondents were asked if the IT strategy supports the business strategy in this organization. Responses were as indicated in Fig 4.5 


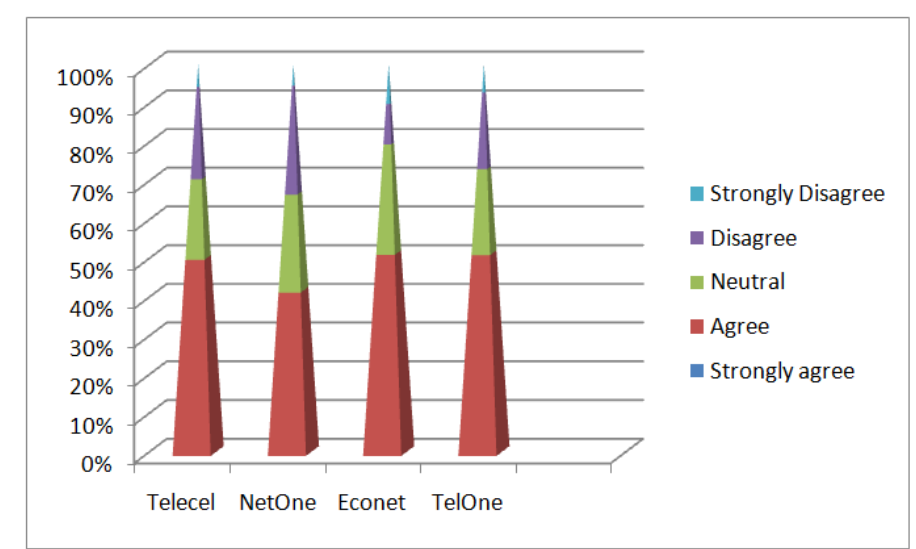

Fig 4.5: Do IT strategies supports Business strategies

Less than $50 \%$ of respondents from all the companies agreed that the business strategy is being supported by the IT strategy. The business strategies are not being complemented by the IT strategies. There is no positive relationship between the Business strategy and the IT strategy.

\subsubsection{Involvement of business managers in IT formulation strategy}

Respondents were asked if the middle level business managers are involved in the IT strategic formulation process. The responses were as shown in table 4.2

\begin{tabular}{|l|l|l|l|l|l|}
\hline Company & $\begin{array}{l}\text { Strongly agree } \\
(\mathbf{\%})\end{array}$ & $\begin{array}{l}\text { Agree } \\
(\mathbf{\%})\end{array}$ & $\begin{array}{l}\text { Neutral } \\
(\mathbf{\%})\end{array}$ & $\begin{array}{l}\text { Disagree } \\
(\mathbf{\%})\end{array}$ & $\begin{array}{l}\text { Strongly Disagree } \\
(\mathbf{\%})\end{array}$ \\
\hline Telecel & 9 & 13 & 33 & 43 & 2 \\
\hline NetOne & 6 & 16 & 42 & 36 & 0 \\
\hline Econet & 13 & 41 & 27 & 19 & 0 \\
\hline TelOne & 5 & 12 & 23 & 54 & 6 \\
\hline
\end{tabular}

Table 4.2 Are middle level managers involved in IT Strategy formulation

A high percent of managers and employees indicated that middle level managers are not involved in the IT strategy formulation. The relationship between Business strategy and IT strategy is not being emphasized since the managers are not involved in the IT strategy formulation.

\subsubsection{Role of IT in Business strategic planning}

Respondents were asked if the IT has any role in the business strategic planning of their organization and their responses are shown in table 4.3 below.

\begin{tabular}{|l|l|l|l|l|l|}
\hline Company & $\begin{array}{l}\text { Strongly agree } \\
(\mathbf{\%})\end{array}$ & $\begin{array}{l}\text { Agree } \\
(\mathbf{\%})\end{array}$ & Neutral & $\begin{array}{c}\text { Disagree } \\
(\mathbf{\%})\end{array}$ & $\begin{array}{l}\text { Strongly Disagree } \\
(\mathbf{\%})\end{array}$ \\
\hline Telecel & 7 & 32 & 11 & 41 & 9 \\
\hline NetOne & 10 & 22 & 15 & 40 & 0 \\
\hline Econet & 9 & 31 & 12 & 32 & 0 \\
\hline TelOne & 5 & 21 & 33 & 41 & 0 \\
\hline
\end{tabular}

Table 4.3 Role of IT in business strategic planning

The majority of managers and employees do not appreciate the importance of IT in the business strategic formulation. They indicated that IT was not very important in planning the business strategy. Thus the relationship between the business strategy and IT strategy to most of them is irrelevant.

\subsubsection{Customer Perceptions on the business-IT Relationship}

Telecommunications customers were asked if the service providers do use IT to market their products effectively. Their responses were shown as in Fig 4.6 below. 


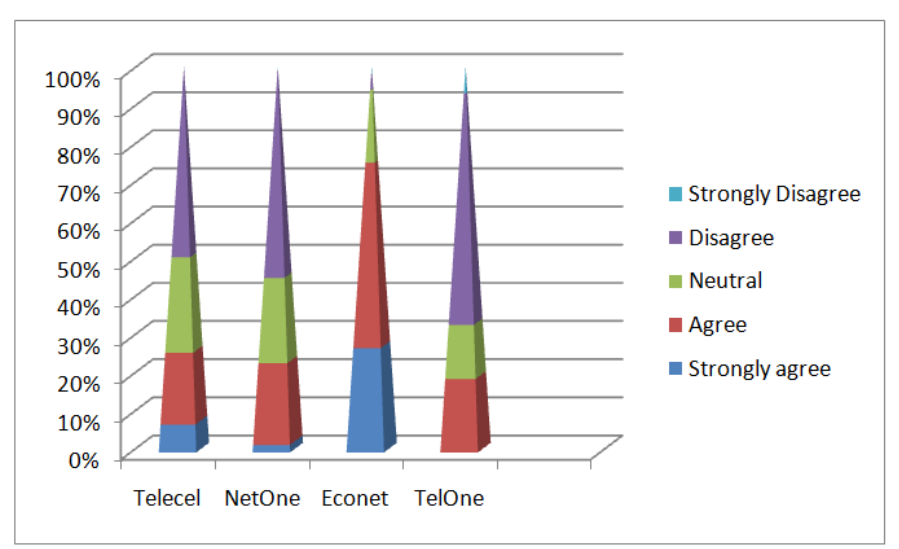

Fig 4.6: Do service providers use IT to effectively market their products

Customers indicated that the telecommunications companies in Zimbabwe are not seen on the market although they do have websites. The websites are never revisited to update on new products and services. The relationship between the marketing strategy and IT is not visible in these organizations. In instances where the IT is applied, it is not being utilized effectively.

\subsubsection{Quality of internet service}

Customers were asked if the internet service they get from their service provider meet their expectations and requirements. The responses were as shown in table 4.4 below.

\begin{tabular}{|l|l|l|l|l|l|}
\hline Company & $\begin{array}{c}\text { Strongly agree } \\
(\%)\end{array}$ & $\begin{array}{c}\text { Agree } \\
(\%)\end{array}$ & $\begin{array}{c}\text { Neutral } \\
(\%)\end{array}$ & $\begin{array}{c}\text { Disagree } \\
(\%)\end{array}$ & $\begin{array}{c}\text { Strongly Disagree } \\
(\%)\end{array}$ \\
\hline Telecel & 6 & 17 & 19 & 48 & 10 \\
\hline NetOne & 5 & 19 & 11 & 51 & 4 \\
\hline Econet & 17 & 34 & 18 & 29 & 2 \\
\hline TeOne & 1 & 15 & 21 & 62 & 1 \\
\hline
\end{tabular}

Table 4.4 Quality of internet service is exceptionally good

The customers are not satisfied with the internet services from all the networks. They indicated the problem of speed and bandwidth as well as the high rate of connection failures with the services. This showed lack of positive relationship between the business strategy and IT strategy since IT is not being used to leverage this noble business strategy of internet facility to the customers.

\subsubsection{Billing process}

Customers were asked if the billing process by their service provider was good. Their responses were as shown in table 4.5 below.

\begin{tabular}{|l|l|l|l|l|l|}
\hline Company & Strongly agree & Agree & Neutral & Disagree & Strongly Disagree \\
\hline Telecel & 17 & 22 & 11 & 44 & 6 \\
\hline NetOne & 19 & 33 & 17 & 31 & 0 \\
\hline Econet & 19 & 47 & 12 & 22 & 0 \\
\hline TelOne & 11 & 15 & 18 & 45 & 11 \\
\hline
\end{tabular}

Table 4.5 Are the customers satisfied with the billing process

Most customers indicated that they were not satisfied with the billing processes of their service providers. The majority of complaints were from the fixed network company (TelOne) where they do not use the prepaid services. The business strategy of billing needs to be supported by high quality, an IT strategy which brings in better and innovative billing platforms. The relationship between the business strategy and IT strategy is shown to be very low in this instance. 


\subsubsection{Company Products and Services}

Customers were asked if they receive regular updates about the company's services and products as well as new products to be launched on the market. Their responses were as shown in fig 4.6.

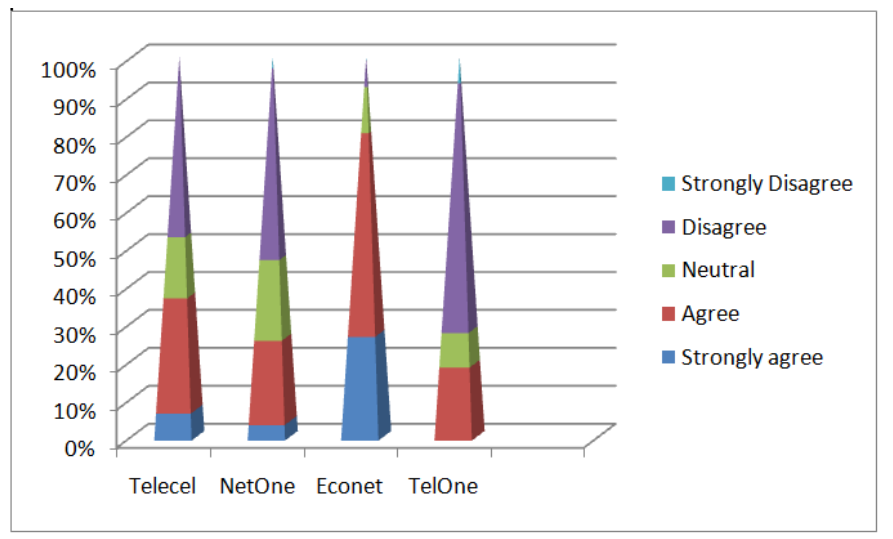

Fig 4.7 Customers receive regular updates about products and services

Econet Customers indicated that they get updates through sms, website or through electronic media and they receive most updates. For the other service providers they showed that they do not get the regular updates and in most cases they get to know about a product after it has been on the market for some time. The companies do not utilize IT effectively to let their customers know about their products. The relationship between the business strategy and IT strategy is very minimal in this regard.

\subsubsection{Business utilize IT for the benefit of customers}

Customers were asked if the telecommunications companies utilize IT for the benefit of the customers. Their responses were as shown in table 4.6 below.

\begin{tabular}{|l|l|l|l|l|l|}
\hline Company & Strongly agree & Agree & Neutral & Disagree & Strongly Disagree \\
\hline Telecel & 15 & 24 & 4 & 53 & 4 \\
\hline NetOne & 17 & 31 & 3 & 49 & 0 \\
\hline Econet & 22 & 44 & 7 & 27 & 0 \\
\hline TelOne & 9 & 21 & 14 & 55 & 1 \\
\hline
\end{tabular}

Table 4.6 Do you benefit from the utilization of IT by the company

An Econet customer agrees that they do benefit from the use of IT by their service provider. Telecel, NetOne and TelOne customers feel they are not benefiting from the use of IT. The Econet customers referred to services like the EcoCash where they can easily make money transactions as some of the benefits of the utilization of IT. This indicated a positive relationship between the business and IT. TelOne customers could not recall any service where they utilize IT and this was a clear sign that the relationship between business and IT was very poor.

\section{Discussion}

The results based on the presented empirical data, discusses the business-IT strategic relationship in the telecommunications industry in Zimbabwe. The discussion was classified into three perspectives: The businessIT scope perspective, business-IT competence perspective, and business-IT governance perspective. Business-IT scope perspective included business scope and IT scope. The business scope of a firm basically presented the core business of the firms which included products or service with specified features and functionality, market and customers. Whereas the IT scope presented the specific information applications and technologies such as information systems implemented by telecommunication organization to support their current business strategy initiatives or create new business strategy opportunities for their organizationIn the four companies within the telecommunications sector in Zimbabwe that were researched on, IT supports business but to a limited extent for all the companies. For instance all the companies use computerised payroll systems in their finance departments. In this case IT supports the business strategy, where the companies have successfully used IT as a business enabler by implementing different software systems to improve customer services in a dynamic business environment. However the companies failed to utilise IT fully for other business strategies. For instance, the telecommunications companies are failing to use IP based strategies to serve their enterprise customers. The IT strategies in the telecommunications sector in Zimbabwe is failing to support the business strategy by not implementing different information systems such as SAP ERP that delivers enhanced capabilities for finance, human capital management, sales procurement, and other key enterprise function to increase work efficiency and enhance business performance. For TelOne and NetOne the strategic plans were on the table for such systems but they are failing to be implemented because of the infrastructure challenges. TelOne is still using the 
copper which is slow for internet connectivity. The other reason for the failure of such systems is resistance by the workforce who feel threatened by the new systems in terms of their work security. This is a result of noninvolvement of middle level managers in the planning processes who were in a position to explain to the workers the importance of such systems. Econetcompany, the strategies were not fullyimplemented as to the alignment of the business strategies. For example the company has expansion strategies which have the resource capital but they are not utilising IT strategies to have services such as Single packet network, which is the strategy to combine voice, data, image, and video into a single packet network. In the long-term, maintaining two parallel networks, circuit-switched for voice and packet-switched for data, as they seen as excessively expensive to their business strategies. Therefore, it is clear that in the four telecommunications companies in Zimbabwe the business scope and IT scope are not harmonized, that is IT scope does not support business scope.Business-IT competencies perspectiveincludes business competencies and IT competencies that fully attributedto the business strategies that contributed to a distinctive, comparative advantage to an organisation over its competitors (Henderson and Venkatraman, 1993). IT competencies refer to the characteristics of the implemented IS/IT in the firm that could contribute positively to create new business strategies or better support of existing business strategies (Henderson and Venkatraman, 1993).Based on the SAM model, Venkatraman argued that to fully leverage IT functionality, business and IT competencies should be integrated and aligned (Henderson and Venkatraman; 1993; Croteau and Raymond, 2004).From the research Econet has one example of IT competency that support business strategy. The real time money transfer service (EcoCash) supports the expansion strategy of the company by increasing the customer base. This positively leverage the business strategy over the other competitors. However the general trend in the industry is the lack of IT competencies that leverage the companies over their competitors. Therefore, in this perspective, it is clear that the business competencies of the companies presented in this research are not consistent and not mutually dependent in their prediction of business performance. Business-IT governance perspective This perspective includes business governance and IT governance. Business governance refers to a wide framework of systems and rules by which a firm is directed and controlled, which includes both internal and external business issues and the decisionmaking rights of the organization. The concept of IT governance in general refers to the organizational capacity exercised by the board, executive management and IT management to control the formulation and implementation of IT strategy to ensure the fusion of business and IT (Van Grembergen, 2007).Based on the SAM model, Henderson and Venkatraman argued that to align business and IT strategies, IT should be linked, and harmonized and compatible with the business governance in the firm. The research showed different approaches in aligning business governance with IT governance for every company on the business circumstances, nature, and needs. Companies in the telecommunications sector in Zimbabwe show IT governance through joint ventures and long term agreements with vendors for obtaining the requisite competencies. The companies do not employ any IT governance framework which can assist them to establish IT governance program in their organisations and ensure consistency in risk management and IS audit.The companies outsource most of their IT services but due to lack of IT governance the systems do not have the support in the organizations for IT to run efficiently. The outsourcing is just being handled by the IT departments only. Therefore based on the results of the research the IT governance and business governance of the telecommunications companies presented are not harmonized and not very compatible.

\section{References}

[1]. Ary,D., Jacobs, L.C., and Razavieh, A., (1990): "Introduction to Research in Education" 4 th edition, Harcourt Brace Jovanovich College Publishers, Fort Worth, USA

[2]. Abdulla, Basahel., (2011): Investigating the Relationship between E-Commerce strategy and IS strategy

[3]. Andriole,S.J.,( 2002): "Information systems engineering", McGraw-Hill Access Science Ecyclopedia of science \& Technology AccessScience@McGraw-Hill, http://www.accessscience.com

[4]. Allen,D.( 1995): Information systems strategy formation in higher Education Institutions, Information research, Vol. 1

[5]. Benemati and leader.,(2000): The role of Information Technology in Management. "The Role of information technology in achieving the organization's strategic development goals"

[6]. Chengchang Wang., and Abhinav Kishore.,(2010): Comparative Research on the Marketing Strategies of Telecommunication Industry in China and India

[7]. Chan,Y, and Huff, S.,( 1993): “Investigating Information Systems Strategic Alignment", in proceeding of the 14 ${ }^{\text {th }}$ International Conference on Information Systems, Orlando, Florida

[8]. Coleman, P. and Papp, R.( 2006): "Strategic Alignment: Analysis of Perspectives", Proceedings of the 2006 Southern Association for Information Systems Conference.

[9]. Croteau,A.M and Bergeron,F.( 2001). An Information Technology Trilogy: Business Strategy, technology Deployment and Organisational Performance, Journal of Strategic Information Systems, Vol, 10

[10]. Croteau, A.M., and Raymond, L., (2004), Performance outcomes of strategic and IT competencies alignment", Journal of Information Technology, Vol. 19.

[11]. Cheo, 2003: The effect of environmental uncertainty and strategic Application of IS on firms Performance. Information Management Journal, Vol. 40

[12]. Collis,J and Hussey,R. (2003): Business Research: A practical guide for undergraduate and postgraduate students. Second Edition, Palgrave Macmillan

[13]. Dooley, D.,( 1995): Social research Methods. Fourth Edition 
[14]. De Vos,A.S, Strydom,H., Fouche,C.B. and Delport,C.S.L (2005): Research at Grass roots: for the social sciences and human services professions. Pretoria: Van Schaik Publishers

[15]. Earl,M.J.,( 1989): "Management strategies for Information Technology", Prentice-Hall, Inc. Upper Saddle River,NJ, USA

[16]. Galliers, R.D.(1993): "Towards a flexible information architecture: integrating business strategies, information systems strategies, and business process redesign" Journal of information systems, Vol. 3

[17]. Galliers, R.D., and Leidner, Dorothy E.,(2003): "Strategic Information Management: Challenges and strategies in Managing Information systems", Elservier Butterworth-Heinemann, $3^{\text {rd }}$ edition

[18]. Guttman H.M. (2004): Alignment unplugged-Bring your talented people together. Executive Excellence

[19]. Henderson J.C., and Venkatraman N. (1991): "Understanding strategic alignment", Business Quarterly, Vol. 55

[20]. Henderson J.C., and Venkatraman,N ( 1993): Strategic alignment: Leveraging information technology for transforming organizations, IBM Systems Journal, Vol. 32

[21]. Hashim, Charles F Hofacker, Sharon Lu, Sarjit Singh,(2006): "The Rlationship between Business Strategy and Internet Evolution: Investigating the Miles and Snow Typology" Springer Vienna

[22]. Hedman, J.,\&Kalling, T.,( 2002): "IT and Business models: Concepts and Theories" Liber Ekonomi, 2002

[23]. Jaska and Hogan, (2006).: How does the alignment of IT to business strategy affect the organization of the IT function?

[24]. Kaplan J. (2003): Optimising business performance: Using IT for competitive Advantage. http://www2.cio.com/research/surveyreport

[25]. Kearns, G.S and andLederer,A.L.(2000): "The effect of strategic Alignment on the use of IS-Based Resources for Competitive Advantage', Journal of strategic Information Systems, Vol. 9

[26]. Kerlinger (1986): "Research design in occupational education: Sampling" $3{ }^{\text {rd }}$ edition. Holt, Rinehart and Winston, New York

[27]. Kinnear,T.C and Taylor, J.R. (1991): Marketing Research. $4^{\text {th }}$ Edition, New York: McGraw-Hill Inc

[28]. Luftman, J.N.1993]: Transforming the enterprise: The alignment of business and information technology strategies. IBM Systems Journal, Vol. 32

[29]. Luftman J. N. (2000): Assessing business-IT maturity. Communications of Association for Information Systems, Vol. 4, Article 14, December 2000

[30]. Luftman, J.N. (2003):" Measure your Business-IT Alignment: The longstanding business-IT gap can be bridged with an assessment tool to rate your efforts", Optimize magazine, December 2003.

[31]. Luftman J. N.(2005). Key Issues for IT Executives 2004, MIS Quarterly Executive Vol. 4

[32]. Manzoni, and Angehrn 1988: Change and Innovation management in IS/IT : A simulation approach

[33]. Mintzberg, H.(1987):” Crafting strategy", Harvard Business Review

[34]. Mintzberg,H., Lampel, J.,Quinn,.J.B., and Ghoshal, S.( 2003]: The strategy Process: Concepts, Contexts, Cases", Fourth Edition, Pearson Education Limited

[35]. Moody, D. (2002): Empirical Research Methods. http://www.idi.ntnu.no

[36]. Myers, M.D. (1997): Qualitative Research in Information Systems. MIS Quarterly, Vol. 21,No.2

[37]. Nicholas Economides (1998): U.S. Telecommunications Today

[38]. Nelson, K. M and Cooprider, J.G (1996): The contribution of shared knowledge to IS Group Performance

[39]. Oates, B.J. (2006): Researching Information Systems and Computing. London: Sage Publications Ltd

[40]. Papp, R. (2001): “Strategic Information Technology: Opportunities for Competitive Advantage," Idea Group Publishing

[41]. Puth,G. (2002): The Communicating leader. Second Edition, Second Edition, South Africa: Van Schaik Publishers

[42]. Picot, A.( 1989): "Information Management- The science of solving problems", International Journal of Information Management.

[43]. Ramakrishna, H.V., and Lin,X., (2000): Perception of the role of information technology function in organizations: toward the development of a measure

[44]. Rogers, E. M. (1986): Progress, problems and prospects for network research: Investigating relationships in the age of electronic communication technologies

[45]. Rockart, J.F, Earl,JM.Ross, J.W. (1996): The new IT Organization: Eight Imperatives

[46]. Sabherwal,R. and Chan, Y. (2001): Alignment between Business and IS strategies: A study of prospectors, Analysers and Defenders, Information Systems Research, Vol. 12, Issue 1

[47]. Saunders, M. Lewis,P. and Thornhill,A. (2003): Research Methods for Business students. $3^{\text {rd }}$ Edition, England: Pearson Education Ltd

[48]. Tavakolian, W., (1991): How does the alignment of IT to business strategy affect the organisation of the IT function?

[49]. Teo, T., and King, W., (1997): "Integration between business Planning and Information systems Planning: an Evolutionary Contigency Perspective", Journal of Management Information Systems Vol. 14

[50]. ThulasonKaira (2010): State of Competition in Zambia's Telecommunications Sector

[51]. Van Grembergen, W.,DeHaes, S., and Van Brempt, H.( 2007): Prioritizing and Linking Business and IT goals in the financial sector, Proceedings of the $40^{\text {th }}$ Hawaii International Conference on System Science

[52]. Ward J. and Peppard J., ( 2002): "Strategic Planning for Information Systems", John Willey \& Sons, Ltd, 3 rd Edition

[53]. Ward J., and Peppard, J., (2004), "Beyond strategic information systems: towards an IS capability", Journal of strategic Information systems

[54]. [Robson, W.,(1997): "Strategic management and Information systems"

[55]. Zmud, R.W., (1989): “Information Technology Management: Evolving Managerial Roles" Financial Executives Research Foundation, Morristown, New Jersey 